\title{
How to Motivate English Learners Faced with Psychological Burden
}

\author{
Himpun Panggabean \\ English Department, Methodist University of Indonesia, Medan, Indonesia \\ e-mail: himpang_25@yahoo.com
}

\begin{abstract}
The misleading assumptions of Indonesian-speaking learners of English on the nature of English results in psychological burden inhibiting the process of teaching and learning. The assumptions should be eliminated at the beginning of English class. Besides, the instructor should extensively motivate and encourage the learners to maximize their potentials in learning process. Such approach will gradually lead the learners to self-confidence and self-discovery.
\end{abstract}

Key words: misleading assumptions, nature of English, psychological burden motivation

As an English instructor in Indonesia, Asia, where English is widely learned, I encounter an important experience fundamentally, closely, and significantly related to the success or failure of teaching and learning process. The experience of which English instructors are not aware is the misleading concepts on the nature of English. Such concepts inhibit the process of how language should be learned. The experience may be of great importance for English instructors throughout the world, particularly for those who teach English in the countries where English is not spoken.

This article takes up what the misleading concepts are, how they inhibit the learners' motivation and negatively affect the way the instructors teach as well as the solution to the problem on the basis of my actual experience in acquiring and teaching English classes in Medan and Bandung, the third and fourth biggest cities in Indonesia.

\section{TYPICAL QUESTIONS}

I am frequently asked typical series of questions concerning English acquisition in numerous occasions, particularly at the beginning of English classes I teach. The questions are "What do I have to do to be able to speak 
English?”, "Why is English very difficult?”, and "I have been learning English for years, why can't I speak English?"

Now and then I am asked whether the failure to catch the native English is due to the fact that the native speakers speak quick English or auditory nerves disturbance and whether the failure to pronounce English sounds is due to anatomical disturbance.

The questions imply that many people desiring to acquire English via formal teaching and learning process have misleading concepts on the nature of English leading to psychological burden. Before starting learning the language, they think that English should be learned in different way in comparison to the ways the other languages are learned, it is more difficult than their native languages and even the most intricate one of all human languages, native English is a quick language, and speech organs of nonnative speakers of English do not match English sounds.

Due to the misleading concepts, many English learners get discouraged, bringing about destructive impact on the teaching and learning process. Many English learners at High School skip English classes and many people intending to learn it delay or even cancel learning it thanks to inherent fear of and dislike for English stemming from the misleading concepts. Therefore, the psychological handicap needs eradicating before English class is commenced.

However, a lot of teachers are not aware of the fact. Despite their awareness, it is not easy to teachers to work out a strategy of satisfying the students' questions that can convince and motivate the learners. They must have linguistic background and vast experience in teaching English to learners from various linguistic and ethnic backgrounds.

It is essential that the English class participants at every beginning of class be offered a chance to put forward questions on anything related to English learning, lest the learners cannot be free from the misleading concepts that have been negatively affecting their thought for a long time. The approach is of great importance for the success of teaching and learning process. When offered such chance, the participants commonly ask the above questions. If their questions are satisfied they will be well motivated.

Motivation plays a very fundamental role in learning processes, including English learning process. Regardless of how idiotic somebody is if he is well motivated, he will be succeeded in learning any language. Therefore, instructors should motivate every learner of English. 


\section{ANSWERS TO THE QUESTIONS}

To answer the above typical questions, I usually, with elaboration in accordance with the learners' linguistic and cultural backgrounds, put forward what Jacobs and Rosenbaum (1968) propose: "Normal infants are born fully equipped to learn any human language spoken anywhere in the world, and all normal children go through more or less the same stages of learning languages, with no language appearing to be more difficult to learn than any other" (p. 28).

Related to the theory is what Finnegan and Besnier (1989) state: “ It is important to recognize that any child who is capable of acquiring some particular human language is capable of acquiring any human language. All children except those with mental or physical impairments acquire their native language in childhood, whatever their culture and whatever their level of intelligence. The ability to acquire language is a fundamental human trait” (p. 15).

Some points being of great importance may be cited on the basis of the theories namely, there are no geographical, cultural, and biological boundaries in learning any language in the world. The learners must realize this and the fact that all normal people, inclusive of them, are born fully equipped to learn and use any human language including English.

The question, what should be done to acquire English, may be satisfied by a recommendation that the language be used continuously. Nobody teaches a native speaker of a language the method of acquiring his language. How he is able to use his language proficiently is thanks to his learning the language continuously. He keeps learning by thinking, listening, and speaking, in the language he is learning.

In short, language-learning process is continuum. If somebody learns English this way, he will be able to use it as perfectly as an English native speaker does, in line with what Jacobs and Rosenbaum (1968) propose that there is no language appears to be more difficult to learn.

Many nonnative speakers learning the second language spend very little time using the second language and thinking in it. They are dependent on classroom learning activities that may occur, say twice a week, each of which lasts for two hours. In the classroom, their teachers teaching in traditional method may not involve them profoundly. This means that the actual time spent in one week is less than four hours. Regardless of how many years they have been learning English in this circumstance, the fact is they learn it in weeks instead of years. 
In terms of language acquisition, very little can be achieved in weeks. Despite the fact that native speakers spend all of their time learning their languages in the places where their languages are spoken, it takes them years to acquire them.

The learners will not find it difficult to understand the explanation because they experienced the same thing in the process of acquiring their native languages. The knowledge on the fact could prevent the learners from thinking that English is a very difficult language to learn. It will not lead them to a true concept that English is not more difficult than any other languages in the world nor is it specific. English is not more difficult than the learners' mother tongues. The thing is not English is difficult, but what the learners think about it and how they learn it.

A concrete evidence to counter the false learners' assumption is the fact that Indonesian-speaking people spending years in English-speaking countries speak English just the way the native speakers of English do when they come back to Indonesia. Similarly, English-speaking people spending years in Indonesia for years such as pastors and guest professors speak Indonesian perfectly. How it takes place, of course, is completely because of their active and dynamic encounter with the languages I assume that the best way of learning a foreign language is to be involved in all conditions where the language is spoken. If only the learners could stay for years in the countries where English is spoken they did not need to learn English in formal English teaching and learning classes.

This means to say, there is no cultural, racial, geographical, biological, and linguistic barrier that can inhibit English language acquisition. Thus, if the learners learn English the way the Indonesianspeaking people do and the way the English-speaking people learn Indonesian, they will certainly acquire English.

With this in mind, the instructors should encourage them to encounter with and learn English extensively by motivating them, for instance, to learn outside classroom and to spend more time practicing it without which, they cannot master it regardless of how much time and fund they have been spending learning English in English educational centers. For the off class learning, the learners' involvement in English speaking-club and English-speaking gatherings such as meeting, church sermons, and English speech competition are of major help. Besides, talking to Englishspeaking tourists, listening to radio, television, and VCD programs as well as getting access to internet are helpful. The latter is in line with what 
Mansor (2007) says, "The technical encroachments of information technology convey impact on the English language learning as it seems to boost students' motivation...."

The purpose of activities outside the classroom is to intensify, as much as possible, the learners' encounter with English and to create atmospheres similar to those of how English is spoken in the countries where English is spoken. The activities outside the classroom are the substitutes of the actual world and significantly support teaching and learning process in the classroom. It is of great significance to motivate the learners to manipulate their own potentials to learn English via access to various English sources as stated previously. This is to guarantee that the role of instructor is a facilitator instead of an authoritarian that forces the learners to abide by curriculum teaching method he has designed.

To implement the approach, tasks can be given to the learners by motivating instead of asking them to find out two things, namely, as I call them, free tasks and targeted task. Free tasks are the activities offered to the learners to find out anything from English sources such as radio, television, Internet, and English-speaking gatherings. Targeted tasks are the tasks offered to the learners by motivating them to learn English topics planned by the instructor with certain standards of complexity in terms of vocabulary and grammar via the multimedia.

Multimedia to which learners get access is a very good means to help learners learn English. Since multimedia offers much English information required by the learners, their interest in information can be engineered by the instructor to be a means of instruction by giving the learners tasks to search for information in English sources.

The activity is very practical. The learners of course are curious to know heat information encouraging them to search for information. Thanks to it, they have knowledge on it from the sources in the languages native to them. Before learning English, the learners search for only information. Now that they learn English, they can be encouraged to achieve two things, information and English

The knowledge on what is being talked about on radios, televisions, and internet can support the effort of acquiring language. For instance, the learners encounter with written discourse in internet say, Thousands of pilgrims jam Rome to attend the funeral of Pope John Paul, some of which words, say, pilgrims and funeral are unknown to the learners. They can predict the meaning of the words in questions by connecting their 
knowledge on the information on the death of the Pope with the words in questions in the discourse. Automatically, the learners' vocabulary and listening abilities are enhanced in this way.

When I taught English to an Indonesian pastor, I motivated him to listen to English cassettes and CD's containing the topics on which he had knowledge namely Christian speeches and songs. Besides, I motivated him to get access to internet. Then we discussed his findings in classroom

He said that the tasks I gave him was very interesting and tremendously improved his listening ability, vocabulary, grammar, and pronunciation. Now the pastor whose English was greatly affected by his vernacular, Hata Batak, and Indonesian national language, Bahasa Indonesia (Indonesian), in terms of accent, intonation, and structure, serves as a secretary general of Indonesian Church Union, PGI as it is called, the position that gives him opportunities to frequently travel overseas where he speaks in English seminars as the representative of Indonesian churches.

Meanwhile, two of my learners who were fully motivated spent one day every week on the average talking to English-speaking tourists and listening to radios and televisions. In six months, they were able to use English proficiently. I got surprised to discover that they were able to use vocabulary and grammar that had not been learned in our class activities.

Regarding task management, as put forward previously, the learners are motivated to do tasks and, in the classroom, they are motivated to share what they found with their friends freely with only a little instructor's intervention. The instructor does not have to, for instance, comment too much on grammar, while the learners are in the process of speaking and listening.

The other class participants should be motivated to respond to their friends' findings. Every one of them should be aware that the chance belongs to them by telling and asking just like in the real world, regardless of various mistakes in pronunciation and grammar they might make. Corrections of pronunciation and grammar may be conducted gradually and should not discourage the learners to use English. The thing to be achieved here is self-confidence of the learners to use English freely as if they used their native languages.

Targeted tasks offered to the learners by motivating them to observe topics planned by the instructor with certain standards of complexity in terms of vocabulary and grammar outside classroom can be conducted by motivating the learners to listen to English-speaking radios and televisions 
or to read internet to cover information on heat news, the death of Pope John Paul II and Prince Charles’ marriage, for instance.

The presentation of the coverage of the tasks in the classroom should be conducted in the same way the free tasks presentation is conducted. When dialogues among the learners begin taking place, the instructor should encourage them to talk more extensively by giving them praises. The instructor might say," Well, your English is good. Go ahead. Exactly..., and so on."

Such strategies are expected to help the learners drop their false concept on the nature of English, encouraging them to learn English the way they want. In this way, the learners will soon find out the fact that they can use English well.

When possible, it is important that the instructor invite English native speakers to the classroom or motivate the learners to talk to native speakers of English outside classroom to prove that their English could be understood by the native speakers and they could understand the native speaker's English at certain levels of complexity though they use different varieties of English.

This kind of experience is great for the learners and brings about motivation and self-confidence to learn English for proficiency - listening, speaking, reading, and writing taking up various issues with various standards of difficulty. When the learners are well motivated to conduct off class learning, they automatically learn the language in the way they desire, the way they learn their native language.

On the basis of this, I conclude that formal class must be accompanied by off class learning to guarantee the true way of learning language and mastery of the language in a relatively short time.

\section{QUICK ENGLISH}

Gleason (1955) states "People speak in sentences, not words. It is very difficult for many people to isolate individual words from sentences" (p. 287). Meanwhile, Finnegan and Besnier (1989) propose "It would be instructive to listen to a conversation in a language you do not know; if you attempt to gauge the number of words in a small sample of even a few seconds, you will discover that most words are run together with no separation - no silences between them”. This is true of all languages. To back up their theory, Finnegan and Basnier give the following example: "Itisasifthesetencesonthispageprintedwithoutspacesbetweenwordsitwouldb everydifficulttofigureoutwouldntit?" (p. 60). 
It would be tough to sort out the individual words in comparison to those run-to gather with the following:

It is as if the sentences on this page were printed without spaces between words; it would be very difficult to figure out, wouldn't it?

The theory is in conjunction with the fact that nonnative speakers learning certain foreign languages find it difficult to catch the speech of the native speakers of the languages due to the inability to separate words from sentences. The difficulty might trigger misguided assumptions of the learners that the native speakers speak quick languages.

With this in mind, the question whether the native speakers of English speak quick English is understandable. The learners of English as the second language may get discouraged when they fail to catch the native speakers' speech and think that English is quicker than their native languages. In fact the English the native speakers speak is English instead of quick or slow English.

The failure is due to the fact that the learners are not accustomed to hearing native English. In natural speech, there are no boundaries separating words one from another. What the hearers catch is continuum of sounds that cannot be clearly or easily understood by those to who English is novel. If the words of sentences of English were spoken individually, the learners would find it easier to catch them. But that is not how a native speaker uses his language.

In addition to the absence of boundaries among words, the modification of sounds can occur because of the effect of neighboring sounds in the process of assimilation, making the work of listening become more complex. To understand better about sound modification, it is important that instructors know what Pike (1968) states that, "sounds tend to be modified by their environments" (p. 58).

Faced with sound complexity, a new learner might think that he hears very quick English. Indeed not only does a learner of English undergo it but also an English native speaker learning another language does. English speaking friends of mine learning Bahasa Indonesia (Indonesian) frequently said to me,"Would you please speak slowly and clearly?"

Therefore, the thing is not whether English is quick or slow, but the learners of it are not used to hearing it. The more they are used to it, the clearer and the more understandable the continuum of sounds will be for them.

Similarly, the failure to pronounce English words perfectly is not due to the inability of the speakers' organs of speech to pronounce them. Many 
English sounds are not available in Bahasa Indonesia (Indonesian), making it difficult for the language users to produce them. When pronouncing such sounds, they make mistakes. It is totally logic. However if the learners of English keep practicing pronouncing English words, they will find out that their worries about their organs of speech are groundless.

The understanding of the learners on why it is difficult to catch native English speech could motivate them to listen to English in any chance. For this objective, I always encourage my learners to have extra listening practices by getting access to English films on television or CD's and English songs and broadcasts. I ask them to listen to anything they like.

The learners take advantages from being asked to hear whatever they like. For instance, I know that they enjoy many English songs although they do not know the words. Being motivated to discover the words, they strive to pay close attention to every single word in the songs. Watching films that the learners enjoy could be a vital instrument of improving their listening ability, for while enjoying the story, they could connect the story to English pronunciation. Listening to radio and television English broadcasts is also fascinating. In Indonesia, BBC and VOA broadcasts are widely heard by people, including the learners because the radios broadcast regularly the latest development of the world, inclusive of Indonesia. At the beginning, the learners commonly admit that they hear nothing. Then I ask them to keep listening while eating, taking bath or doing any other activities without making the work of listening a work. After sometime, they do hear English words. Finding out the improvement I ask them to connect what they know about the news to the broadcast in order for them to be able to catch long and complex utterances. This kind of approach is profoundly effective in improving the learners' listening ability.

Such approach, particularly to listening improvement, has to be supported and initiated by classroom activities. The instructor should arrange time allotment for listening and select listening materials to which the learners are intimate. For this objective, the instructor may ask what the learners want to hear. The approach is adopted on the basis of what the learners need as proposed by learner-centered education approach. According to Nunan (1999), in Communicative Language Teaching (CLT), learners should be allowed to create their own goals

The instruments used in this activity could be tape recorders and videos as well as live English broadcasts on radios or televisions. 
Conducting the strategy, I encourage the learners to use English the way they want in condition that their English is understandable and communicative. At the beginning, I always let my learners speak English in the pronunciation, accent, stress, and intonation of their native languages. Later on, I try to correct their pronunciation, accent, stress, intonation, and grammar. The concept underlying the approach is that using English extensively is better than using it correctly in relatively limited opportunity.

\section{CONCLUSION}

In Indonesia, most of English learners, especially the beginners have misguided assumptions on the nature of English, bringing about bad learners' motivation. The assumptions are English is the most difficult language in the world, and the nonnative speakers' speech organs and ear might not match English. Not only do the misguided assumptions bring about learners' poor motivation but also negatively affect the ways instructors teach.

To achieve the actual objective of learning English, such assumptions need preventing. One of the effective approaches to eliminate the negative assumptions is to motivate the learners to manipulate their potentials to learn English they way they want by doing tasks outside the classroom, for example, listening to English radios and televisions, joining Englishspeaking gatherings, talking to English native speakers, and getting access to internet.

The instructors' role to deal with the phenomenon is a must. The instructors and the learners must be who they are who are able to use any language of the world, including English.

\section{REFERENCES}

Finnegan, E., \& Besnier, N. (1989). Language, its structure, and use. Sandiego: Harcourt Brace Jovanich.

Gleason, Jr. H. A. (1985). An introduction to descriptive linguistics. New Delhi: Oxford \& IBH Publishing Co.

Jacobs R. A., \& Rosenbaum P. S. (1999). English transformational grammar. Massachusetts: Blasdell Publishing Company. 
Nunan, D. (1999). Second language teaching and learning. Boston: Heinle \& Heinle Publishers.

Mansor, N. (2007). Collaborative learning via email discussion: Strategies for ESL writing classroom. Retrieved July 14, 2007, from http://itesj.org/ Techniques/ Mansor-EmailDiscussion/

Pike, K. L. (1968). Phonemics: A technique for reducing language to writing. Michigan: University of Michigan Press 